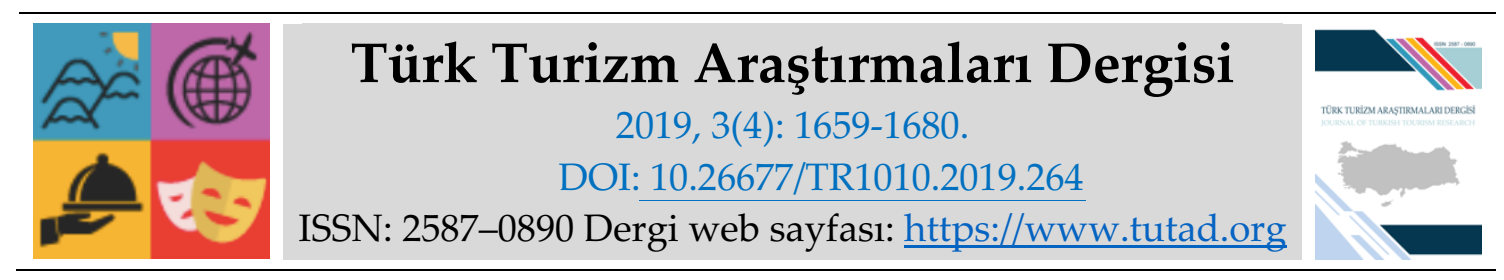

KAVRAMSAL MAKALE

\title{
Türk Mutfağındaki Fonksiyonel Gıdaların Gastronomi Turizmi Açısından Önemi
}

Arş. Gör. Emel ÇİRişOĞLU, İstanbul Gelişim Üniversitesi, Güzel Sanatlar Fakültesi, İstanbul, eposta: ecirisoglu@gelisim.edu.tr

ORCID: https://orcid.org/0000-0003-0233-2036

Dr. Öğr. Üyesi Emine OLUM, İstanbul Medipol Üniversitesi, Güzel Sanatlar Tasarım ve Mimarlık Fakültesi, İstanbul, e-posta: eolum@medipol.edu.tr

ORCID: https://orcid.org/0000-0002-7188-817X

Öz

İnsanların öncelikli ihtiyaçlarından olan beslenme, aynı zamanda temel bir motivasyondur. Günümüzde beslenme, yeni bir yemeği tatmak ve farklı lezzetler ve aromalar deneyimlemek uğruna seyahat edilen bir amaç haline gelmiştir. Bu deneyimleme isteği gastronomi turizminin bir parçası olarak sektörün gelişimine katkıda bulunan, turistik faaliyetleri canlandıran bir etkendir. Yeni dünya düzeniyle birlikte insanlar, sağlıklı bir hayat sürebilmeleri için sağlıklı beslenme gerekliliğinin farkındadır. Sağlıklı gıdalara gösterilen ilgi, fonksiyonel gıdalar hakkında hizmet sektörünün bilinçlenmesi ve bu trende karşılık, sektör için yeni faaliyet planlamalarının geliştirilmesini gerekli kılmaktadır. Bu çalışma ile Türk mutfağındaki bazı fonksiyonel gıdalar tanıtılmış ve turizme yapacağı katkılar vurgulanmıştır. Çalışmada, kaynak taraması yapılarak konu ile ilgili literatür incelenmiş ve derleme bir çalışma oluşturulmuştur. Literatür incelemesi sonucunda en çok karşılaşılan sorun, ürünlerin tanıtımı ve pazarlama faaliyetlerindeki yetersizliklerdir. Yöresel yiyeceklerin tanıtımında yaşanan bu sorunlar, yörelerde fonksiyonel gıdaların ön plana çıkmasını engellemekte ve bazı gıdaların bilinirliğini ve yaygınlaşmasını olumsuz etkilemektedir.

Anahtar Kelimeler: Yeni Trendler, Sağliklı Beslenme, Yöresel Gıdalar, Turizm Endüstrisi.

Makale Gönderme Tarihi: 21.06.2019

Makale Kabul Tarihi: 03.10.2019

\section{Önerilen Atıf:}

Çirişoğlu, E. ve Olum, E. (2019). Türk Mutfağındaki Fonksiyonel Gıdaların Gastronomi Turizmi Açısından Önemi, Türk Turizm Araştırmaları Dergisi, 3(4): 1659-1680.

(C) 2019 Türk Turizm Araştırmaları Dergisi.

*Bu makale 01-03 Kasım 2018 tarihlerinde Sakarya'da düzenlenen “1. Uluslararası Turizmde Yeni Jenerasyonlar ve Yeni Trendler Kongresi'nde bildiri olarak sunulmuş, bildiriler kitabında özet metin olarak yer almış ve geliştirilerek makale haline getirilmiştir. 


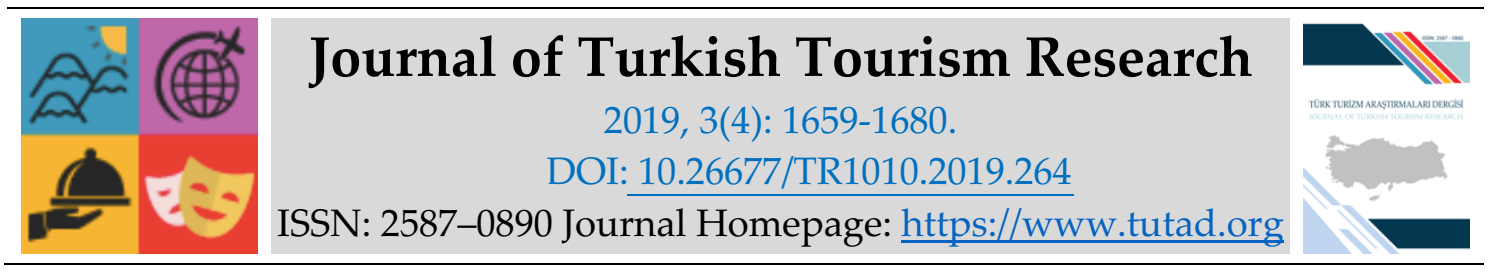

\title{
CONCEPTUAL PAPER
}

\section{The Importance of The Functional Foods in Turkish Cuisine in Terms of Gastronomy Tourism}

Research Assistant Emel çíRİ̧̧OĞLU, İstanbul Gelişim University, Faculty of Fine Arts, İstanbul, e-mail: ecirisoglu@gelisim.edu.tr ORCID: https://orcid.org/0000-0003-0233-2036

Assistant Prof. Dr. Emine OLUM, İstanbul Medipol University, Faculty of Fine Arts, Design and Architecture, İstanbul, e-posta: eolum@medipol.edu.tr ORCID: https://orcid.org/0000-0002-7188-817X

\begin{abstract}
Nutrition is not only the primary need for the survival of people, also one of the basic motivations. Nutrition has become a travel goal in an attempt to taste a new dish or to experience different tastes and flavors. The desire of this experience is a factor that contributes to development of tourism sector as a part of gastronomy tourism and stimulates the touristic activities. New world circumstances have made people more aware of the necessity of a healthy diet to live a healthy life. The increasing interest towards healthy foods increased awareness about functionality of foods and make it necessary to develop new activity plans in the service industry. The present review was introduced some functional foods in Turkish cuisine and emphasized their contributions to tourism industry. In this study, literature review is done and a review is prepared. As a result of the literature review, the most common problem is the deficiencies in the promotion of products and marketing activities. These problems in the promotion of local foods prevent functional foods from becoming prominent in the region and adversely affect the recognition and spread of some foods.
\end{abstract}

Keywords: New Trends, Healthy Nutrition, Traditional Foods, Tourism Industry. Received: 21.06.2019

Accepted: 03.10.2019

\section{Suggested Citation:}

Çirişoğlu, E. and Olum, E. (2019). The Importance of The Functional Foods in Turkish Cuisine in Terms of Gastronomy Tourism, Journal of Turkish Tourism Research, 3(4): 1659-1680.

(c) 2019 Türk Turizm Araştırmaları Dergisi. 


\section{Gíriş}

Nutrigenomik (Gen dizilimine göre beslenme) ve bireyselleştirilmiş beslenme çağına geçilen bu dönemde insanlar artık tükettikleri gıdaların sağlık açısından fayda ve zararlarına daha çok dikkat etmeye başlamıştır. Alınan gıdalar ile temel beslenme ihtiyacının karşılanması yanında, bu gıdaların sağlığa ekstra fayda sağlaması, günümüzde en popüler beslenme konularından biri haline gelmiştir. Bu durumda, fonksiyonel gıda terimi ortaya çıkmaktadır. Fonksiyonel gıdalar, temel beslenme ihtiyacını karşılamasının ötesinde, doğrudan ya da içerisinde bulunan bir bileşen sayesinde, ek olarak sağlığa fayda sağlayan gıdalardır. Fonksiyonel gıdaların tarihine bakıldığında ise, bu kavramın ilk olarak Japonya'da kullanıldığı görülmektedir. Japonya'da nüfusun çoğunluğuna sahip olan yaşlı kesimin yaşam kalitesini yükseltmek, hastalıkları azaltmak için gidaların sağlık üzerindeki etkileri araştırılmaya başlanmış ve neticede fonksiyonel gıda kavramı ortaya çıkmıştır (El Sohaimy, 2012 Aktaran Daliri ve Lee, 2015). Hipokrat ise, bu konu üzerine söylediği "İlacınız besinleriniz, besinleriniz ilacınız olsun" sözü ile yüz yıllar önce gıdaların fonksiyonel özelliklerine vurgu yapmıştır (Bağıran Özşeker, 2017). Avrupa Gıda Bilgi Konseyi'nin tanımına göre fonksiyonel gıdalar; takviye edilmiş ve zenginleştirilmiş gidalar, diyet takviyeleri ve sağlıklı gıdaları içermektedir (El Sohaimy, 2012 Aktaran Daliri ve Lee, 2015). Fonksiyonel gıdalar, insan vücudunun genel durumunu iyileştirme, hastalıkların oluşumunu azaltma gibi faydalarından dolayı oldukça önemlidir (Bağıran Özşeker, 2017). Ayrıca, sağlık üzerindeki potansiyel faydaları ve farklı hastalıklar için önleyici veya tedaviyi destekleyici rollerinin olduğu, birçok çalışmada ortaya koyulmuştur (Rafter, 2002; Roberfroid, 2002; Coşkun, 2017; Bağıran Özşeker, 2017; Singh vd., 2019; Takahashi vd., 2019).

Günümüzde gıdaların fonksiyonel özellikleri üzerine artan tüketici ilgisi ve bilinç düzeyi ile birlikte, bu gıdalar mutfaklarda daha çok kullanım alanı bulmuştur. Son yıllarda meyve ve sebzeler, baklagiller, tahıllar, faydalı tohumlar, şeker ve tuz içeriği azaltılmış gıdalar ve glüten içermeyen ürünlere olan talep, adeta bir trend haline gelmiştir (Riezzo vd., 2005). Kırmızı reishi mantarı, karabuğday, shiitake mantarı, camu camu, yaban mersini, avakado, chia tohumu, keten tohumu, kinoa gibi fonksiyonel gıdalar artık hemen hemen her ülke mutfağına ulaşmakta ve bu gidaların fonksiyonel gida trendi ile pazarlaması kolaylıkla yapılmaktadır (Ercan, 2015).

Tam da bu noktada Türk mutfağının içinde barındırdığı zengin kültürel ve tarihi birikim ile Türk mutfağında kullanılan gıdalar ve yöresel yemeklerin daha çok tanıtılarak, kullanılan gıdaların sağlığı iyileştirici özellikleri hakkında bilgilendirmeler yapılmasının hem turizm hem de tarım ekonomisine oldukça katkı sağlayacağı düşünülmektedir. Çalışmaya konu olan söz konusu fonksiyonel gıdaların; özellikle Boğatepe gravyer peyniri, Kastamonu siyez buğdayı, yaban mersininin Türkiye'ye özgü ve daha fazla antioksidan içeriğine sahip türdeşi maviyemiş, 30 çeşit şifalı bitki içeren Van otlu peyniri, Amerikan Kanser Araştırmaları Enstitüsü tarafından dünyadaki antikanser olarak nitelendirilen 7 yiyecek içerisine Türkiye' den dâhil edilen mercimek köftesi, kökeni Türkiye'ye ait olmamasına rağmen Türk kültürü, misafirperverliği ve gelenek ve görenekleriyle bütünleşip, tüm dünyada Türk kültürüyle tanınan Türk kahvesi gibi yiyecek ve içeceklerin fonksiyonel özelliklerinin de bilinmesi ve bu ürünlerin mutfaklarda yaygın kullanılır hale gelmesi istenmektedir. Bu konuda yapılacak olan yenilikçi turizm faaliyetleri için Türk mutfağının geniş bir altyapıya sahip olduğu aşikârdır (T.C. Kültür ve Turizm Bakanlığı, 2013; Topuk, 2014; American Institute for Cancer Research, 2015; Özçelik, 2015; Arınç, 2018; Slow Food Foundation, 2018).

Bu çalışmanın amacı modern çağda ortaya çıkan yeni hastalıklar ile birlikte insanların artık doğal olana yönelme eğilimleri göz önünde bulundurulduğunda, gastronomi turizmi açısından önemli bir geleceğe sahip olduğu düşünülen Türk mutfağındaki fonksiyonel gıdaları incelemek ve önemini ortaya koymaktır. Türk mutfağının hâkim olduğu geniş coğrafya, tarımsal ve hayvansal 
ürün çeşitliliği, içinde barındırdığı çeşitli kültürler düşünüldügünde, fonksiyonel gidalar açısından Türk mutfağının incelenmesinin öncelikle yöre halklarında bilinç yaratmak, daha sonra bu konuya dair çalışmaların çoğaltılmasını teşvik etmek ve çok yeni bir alan olan Gastronomi biliminin gelişmesine katkı sağlamak açısından önemli olduğu düşünülmektedir.

\section{FONKSIYYONEL GIDALAR VE GASTRONOMIDEKİ YERİ}

Son yıllarda artan çeşitli hastalıklar sebebiyle, gıdaların besleyici değerlerinin ötesinde sağlığa olan olumlu katkıları üzerinde durulmaktadır. Bu bakımdan da fonksiyonel gıda terimi popülerlik kazanmaya başlamıştır (Hasler, 2002). Fonksiyonel gıdalar ile ilgili son yıllarda yapılan çalışmalar meyve, sebze ve diyet liflerinin (bitki bazlı posalı gıdalar) ağırlıkta olduğu beslenme şeklinin kardiyovasküler hastalıklar, obezite, diyabet gibi kronik hastalıkların riskini azalttığını ve insan sağlığını iyileştirdiğini açıkça göstermektedir (Vural, 2004; Coşkun, 2005; İşleroğlu, Yıldırım vd., 2005; Sevilmiş, 2008; Balçık Mısır, 2012). Ayrıca, dünya çapında yapılan birçok bilimsel araştırmada, bitkilerdeki biyoaktif bileşiklerin antioksidan, antiseptik, antikanserojen, antitümoral, antibakteriyel özelliklere sahip oldukları ortaya koyulmuştur (Balsano ve Alisi, 2009 Aktaran Cencic ve Chingwaru, 2010; Cencic ve Chinwaru, 2010).

İnsan vücudu üzerinde olumlu etkilere sahip olan, sağllğ̆ geliştirici özellikleri bulunan ve belirli hastalıklara yakalanma risklerini azaltan bileşenler içermesi sebebiyle günümüzde daha çok tüketilen fonksiyonel gıdalar yeni gastronomi trendleri arasında yerini almıştır. Nüfus yapısındaki demografik ve sosyoekonomik değişiklikler, sağlık yararı olan gıdalara talebi artırmış ve böylelikle tüketiciler sadece lezzet değil, aynı zamanda sağlık arayışında olmaya başlamıştır. Dışarıda yemek yeme olgusunun günlük bir rutin haline geldiği günümüz yaşam koşullarında restoran menülerinin fonksiyonel gıdalar içermesi, yeme içme sektörü açısından son derece önemli görülmektedir (Daliri ve Lee, 2015). Fonksiyonel gıdalar, tarihinin çok eskilere dayanmasına rağmen, gastronomi ve mutfak sanatları açısından yeni bir yaklaşımdır. Her ne kadar gastronomide yeni trendler arasında görülse de aslında bu trend mevcut fonksiyonel gıdaların tanıtımının yapılması, menülerde bu gıdalara yer verilmesi ve turizm açısından da bir çekicilik unsuru olarak görülüp öneminin ortaya çıkarılmasıyla ilişkilidir. Özellikle Türk yemek kültürünün bir parçası olan ve yüzyıllardır tüketilen fonksiyonel özelikteki gıdaların öneminin kavranıp bu gıdalar ile ilgili gerekli girişimlerin yapılması ile Türk Gastronomisinin ve gastronomi turizminin gelişimine önemli katkılar sağlanacağı açıktır. Bu bağlamda mevcut coğrafi işaretli ürünlerden fonksiyonel olanların belirlenmesi, mutfaklarda çok sık kullanılan fonksiyonel gıdaların araştırılması, bu gıdaların sağlık üzerindeki faydalarının tespit edilerek daha bilinçli bir şekilde menüler oluşturulması, yöresel menülerde yer alan mevcut fonksiyonel özellikteki bileşenlerin ve gıdaların vurgulanması ancak yerel yönetimlerin, üniversitelerin ve turizm işletmelerinin iş birliği içerisinde çalışması ile mümkündür.

\section{YOĞURT}

Türk Gida Kodeksi Fermente Süt Ürünleri Tebliği (Tebliğ No: 2009/25)'ne göre yoğurt, "Fermentasyonda spesifik olarak Streptococcus thermophilus ve Lactobacillus delbrueckii subsp. bulgaricus' un sinbiyotik kültürlerinin kullanıldığı fermente süt ürünü" olarak tanımlanmıştır (Resmi Gazete, 2009). Yoğurt, içerdiği probiyotik bakteriler sayesinde bağırsak florasını düzenlemekte ve başta kolon kanseri olmak üzere birçok hastalık için önleyici rol üstlenerek, bağışıklık sistemini güçlendirmektedir. Aynı zamanda, sindirim sistemi rahatsızlıklarını gidermekte, kemik erimesini önlemekte, kolesterol düzeyinin düşmesini sağlamakta ve beyin fonksiyonlarının iyileştirilmesine yardımcı olmaktadır (Fernandez ve Marette, 2017; Lourens ve 
Viljoen 2001). Bunların yanında, içerdiği B2, B12, D vitamini, riboflavin, kalsiyum, magnezyum, fosfor, iyot, potasyum ve çinko gibi zengin vitamin ve mineral maddeler yönüyle de besleyici değeri yüksek, fonksiyonel özellikte bir gıdadır. Yoğurdun içerdiği yararlı bakteriler sayesinde, bağırsaklar üzerinde olan olumlu etkisine ek olarak psikolojik açıdan da yarar sağladığı artık bilimsel çalışmalarla ortaya koyulmuştur. Yoğurt, yüksek besleyici değeri olması ve kolay sindirilebilir özelliği ile günlük beslenmede oldukça önemli bir rol oynamakta ve Türk mutfağında çok yaygın bir kullanım alanı bulmaktadır (Fernandez ve Marette, 2017). Demirgül ve Sağdıç (2018) da yaptıkları çalışmada, yoğurdun antikarsinojenik, antimikrobiyal ve antihipertansiyon özelliklerinin bulunduğunu belirtmişlerdir. Bir diğer çalışmada ise Şireli ve Onaran (2016), yoğurdun içerdiği protein, mineral ve vitaminler hakkında bilgi verdikten sonra, yoğurdun sağlığı geliştirici özellikleri üzerinde durmuştur.

Yoğurdun ilk olarak ortaya çıkışı çok kesin olmamakla birlikte, mevcut bilgiler Orta çağda göçebe olarak yaşayan Türkler tarafından tesadüfen keşfedildiğini göstermektedir. Yoğurdun ortaya çıkışı ve Orta Çağ' da Türkler tarafından ilk kullanımına dair yazılı belgeler, 11. yüzyılda kaleme alınmış olan Divanı Lügat-it Türk ve Kutadgu Bilig adlı eserlerdir (Fisberg ve Machado, 2018). Türkler, sakladıkları sütlerin kendiliğinden ekşidiğini ve yoğunlaştığını fark etmiş ve daha sonra bu özellikten faydalanarak yoğurt yapmaya başlamışlardır. Bu sayede, ilk önce Anadolu ve Orta Doğu, daha sonra ise Avrupa Ülkeleri Türkler aracılığıyla yoğurt ile tanışmışlardır (Şireli ve Onaran, 2016). Yoğurt üretiminin bu denli eskilere dayanması ve günümüzde yaygın olarak tüketilmesi ise, Türk kültürüne ait köklü bir gıda olduğunu göstermektedir. Ayrıca yoğurt; çorba çeşitlerinde, yöresel yemeklerde, kebaplarda, soslarda, salatalarda, mezelerde, hamur işlerinde ve marinasyonda kullanılarak Türk mutfak kültüründe geniş bir kullanım alanı bulmaktadır. Yoğurdun yapılışının basit olması ve çabuk bozulan sütün uzun süreli muhafazası için bir alternatif oluşturması tüketimini yaygınlaştırmış ve günümüze kadar üretiminin devam etmesini sağlamıştır (Fisberg ve Machado, 2015; Şireli ve Onaran, 2016). Yoğurda ait görsel Resim 1'de gösterilmektedir.

\section{TAŞKÖPRÜ SARIMSAĞI}

Sarımsak, güçlü antioksidan özelliği sayesinde, insan sağlığı için oldukça faydalı bir gıda olması yanında, yüzyıllardır geleneksel tıpta tedavi amaçlı kullanılan fonksiyonel bir gidadır (Avcı ve Erdoğan, 2017; Canbolat, 2017). Prebiyotik olan sarımsak, bağışıklık sistemi üzerinde yararlı etkilere de sahiptir. Sarımsağın kolesterol ve kan basıncını düşürücü etkisi yanında kalp damar hastalıklarında iyileştirici rolü de bulunmaktadır. Antitümör, antiviral, anibakteriyel özellikleri ile bilinen sarımsak oldukça faydalı bir besin maddesidir (Ayaz ve Alpsoy, 2007; Alıç ve Ceyhan, 2012). Türkiye' de selenyum açısından zengin toprağı ile Kastamonu Taşköprü ilçesinde yoğun olarak üretimi yapılmaktadır. Taşköprü sarımsağının; keskin ve karakteristik tadı, kokusu ve aroması, kendine özgü acılığı, bir baş sarımsakta bulunan tanelerin iriliği (60 grama kadar çıabilmektedir), selenyum açısından zengin topraklarda yetişmesi ile anti kanserojen özelliğinin fazla olması, Taşköprü sarımsağını diğer sarımsak türlerinden ayıran ve önemli kılan özelliklerdir (Türk Patent Enstitüsü, 2009). Taşköprü sarımsağına ait görsel Resim 2'de gösterilmektedir.

Sarımsağın yemeklere yoğun lezzet katması Türk ve Dünya mutfaklarında çok geniş bir kullanım alanı oluşturmaktadır. Sarımsak, başlı başına bir ana yemek (sarımsak kebabı) veya içecek maddesi (sarımsak çayı) olabildiği gibi, sos, meze, çorba, kebap, aperatif tariflerde çĭ̆, pişmiş veya toz olarak kullanımı ve yemeklerin lezzetini artırıcı rolü ile mutfakta oldukça çeşitli bir kullanım alanı oluşturmuştur. Taşköprü sarımsağının üstün fonksiyonel özelliklerinin bulunması ve coğrafi işaret alarak tescillenmesi hem ülke ekonomisine hem de yerel üreticiye 
katkı sağlaması yönünden önemlidir. Ayrıca kullanım alanının genişliği de Taşköprü sarımsağının pazar payının genişletilmesi için bir fırsat yaratmakta ve tüm dünyada Taşköprü sarımsağına olan ilginin artması ile tarım ekonomisinin canlanmasına da fayda sağlamaktadır (Canbolat, 2017; Avcı ve Erdoğan, 2017).

\section{SIYYAH SARIMSAK}

Siyah Sarımsak, taze sarımsaktaki gibi keskin ve karakteristik kokunun olmadığı işlenmiş bir üründür. Beyaz sarımsağın $60^{\circ} \mathrm{C}^{\prime}$ de ve yüksek nem (\%85-90) ile 30 günden fazla bir süre boyunca fermente edilmesi ile oluşmaktadır. Siyah sarımsağın ilk üretimine dair bilgiler ise, rahatsız edici ve yoğun kokusunu gidermek için Kore ve Japon araştırmacılar tarafından başlatılmış ve 2003 yılında, fermantasyon işlemi ile siyah sarımsak elde edilmiştir (Akan, 2014). Fermantasyon sürecinde sarımsak, maillard reaksiyonu da dâhil olmak üzere birçok reaksiyondan geçmekte ve bunun sonucunda besin içeriği, tadı ve kokusunda birtakım değişiklikler meydana gelmektedir. Fermantasyon ile sarımsak dişlerinin rengi koyulaşmaya başlar ve sarımsağın keskin kokusu ve tadı, yerini koyu jöle kıvamında, tatlımsı ve siyah renkte bir ürüne bırakır (Wang vd., 2016). Fonksiyonel bir gıda olan siyah sarımsağın, yapılan çalışmalarda taze sarımsağa kıyasla daha güçlü antioksidan ve antikanserojen özelliklere sahip olduğu belirtilmiştir (Kim vd., 2013; Dong vd., 2014; Yoo vd., 2014). Diğer türdeşlerinden üstün özelliklere sahip Kastamonu Taşköprü' deki coğrafi işaretli sarımsaklardan elde edilen, besin değeri yüksek siyah sarımsağın mutfaklarda kullanımı ve bilinirliği günümüzde daha çok artmış ve aynı zamanda önemli bir ihraç ürünümüz haline gelmiştir (TPE, 2009). Taze sarımsağın keskin kokusu ve tadı siyah sarımsakta olmadığı için sıcak mutfak, soğuk mutfak ve pastane ürünlerinde daha sık kullanım alanı bulmaktadır. Siyah sarımsağa ait görsel Resim 3'te gösterilmektedir.

\section{ŞALGAM SUYU}

Şalgam suyu, laktik asit fermantasyonu ile üretilen geleneksel fermente bir Türk içeceğidir (Resim 4). Üretiminde bulgur, tuz, su, mor havuç, şalgam ve bazen kırmızı pancar kullanılmaktadır. Doğrudan üretim ve geleneksel üretim yönetimi olmak üzere iki farklı şekilde üretilmektedir. Birinci yöntemde, kullanılan malzemeler doğranmakta ve içerisine ekmek mayası eklenerek oda sıcaklığında fermantasyona bırakılmaktadır (Üçok ve Tosun, 2012). Geleneksel yöntem ise iki aşamadan oluşur. İlk aşama ilk fermantasyon, ikinci aşama ise ana fermantasyon olarak adlandırılmaktadır. İlk aşamada, laktik asit bakterilerinin zenginleştirilmesi için bulgur unu, tuz, ekşi hamur ve su karıştırılır ve daha sonra karışım oda sıcaklığında 3 ila 5 gün fermantasyona bırakılır. Bu süreçte karışımın pH oranı düşer. Bu şekilde fermantasyondan elde edilen özüt, ana fermantasyon için iyi bir başlangıç olmaktadır. Birinci aşamadan elde edilen özüte siyah havuç, şalgam ve yeterli miktarda su eklenerek ikinci fermantasyona bırakılır. Bu sürecin sonunda, kırmızı ekşi bir içecek olan şalgam suyu elde edilmektedir (Erten vd., 2008). Şalgam suyu, probiyotik olması yanında kalsiyum, potasyum, demir, B-karoten, B grubu vitaminlerini de içermesi ile iyi bir besin kaynağıdır. Bunun yanında, düşük kalorili bir içecek olması, fonksiyonel özellikteki bu geleneksel içeceğin önemini artırmaktadır. Mor havuçta bulunan ve şalgam suyuna rengini veren antosiyaninler, doğal renk maddesi olma özelliği yanında içerdiği antioksidanlar sayesinde sağllğı geliştirici, antikanser ve kardiyovasküler hastalıkları azaltıcı özelliktedir (Turker, Aksay ve Ekiz 2004). Şalgam suyu, özellikle Mersin, Kahramanmaraş, Adana, Hatay gibi Türkiye'nin Güney Bölgelerinde daha çok tüketilmektedir (Gögüşs vd., 2016; Coşkun, 2017). İyi kalitedeki şalgam sularına restoran menülerinde daha çok 
yer verilmesi ve çalışanların sağlık fonksiyonları hakkında bilgi düzeyinin artırılması, içeceğin tanıtımına katkı sağlanması açısından gereklidir.

\section{KEFIR}

Kefir, eski çağlardan beri sağlık için birçok yararı olduğu bilinen, en eski probiyotik gıdalardan biridir. Kefirin tarihine dair bilgiler ise, Kafkas dağlarında Müslüman halklar tarafından keşfedildiğini göstermektedir. Orta Asya'da binlerce yıldır tüketilmekte olan kefir, o bölgede yaşayan halkların nesilden nesile, bir aile mirası gibi günümüze kadar taşıması ile korunmuştur. Diğer probiyotik ürünlerden çok daha karmaşık bir yapısı olan kefir, çok sayıda farklı bakteri ve maya içermesiyle, benzersiz bir kimyasal bileşime sahiptir. Kalsiyum ve proteince zengin olan kefir, fermente bir ürün olması sebebiyle sindirilirliği yüksek bir gıdadır (Kesenkaş vd., 2017). Ayrıca önemli miktarda amino asit, vitamin ve mineral bileşenlerini ihtiva etmektedir. Geçmişte tıbbi tedavi mümkün olmadığında, kefirin iyileştirme gücüne sahip olduğu, tüberküloz ve gastrointestinal bozukluklar gibi bazı hastalıkların tedavisinde kullanıldığı bilinmektedir. Kefirin işlevselliği üzerine birçok bilimsel çalışma yapılmış ve kefirin antibakteriyel, antikanserojen, antidiyabetik ve kolesterol düşürücü etkileri olduğu kanısına varılmıştır (Köroğlu vd., 2015; Türkmen, 2017; Kesenkaş vd., 2017). Sağlığa yararı ve bağışıklık sistemini destekleyici etkisi nedeniyle, önemli bir fonksiyonel süt ürünü haline gelmiştir ve tüketimi dünya çapında artmıştır (Güzel Seydim vd., 2011). Mutfakta ise soslarda, çorbalarda kullanılabilmekte ya da içerisine meyve eklenerek de tüketilebilmektedir (Karaçıl ve Acar Tek, 2013). Tüm dünyada, üzerine araştırmalar yapılan ve sağlık üzerine olan çok önemli faydaları kanıtlanmış olan bu probiyotik gıdanın, tanınırlığının artması ve kullanımının yaygınlaşması, Orta Asya'da yaşayan Türkler aracılığıyla gerçekleşmiştir. Bu durum Türk Mutfağının ne kadar köklü bir geçmişe sahip olduğunun önemli bir göstergesidir (Libudzisz ve Piatkiewicz, 1990; Roberts vd., 2000 Aktaran John ve Deeseenthum, 2015). Kefirin değerinin anlaşılması ise, Rus bilim insanlarının 1920'li yıllarda yapmış olduğu araştırmalar neticesinde, kefirin içerisinde bulunan çok sayıda probiyotik bakteri olduğunun öğrenilmesi ile gerçekleşmiştir (Aghatabay, 2005; Tomar, Çağlar ve Akarca, 2017). Kefire ait görsel Resim 5'te gösterilmektedir.

\section{TARHANA}

Tarhananın geçmişi 6 ve 7. yüzyıllar kadar eskiye dayanmaktadır. Göçebe halde yaşayan Türklerin yerleşik hayata geçtikten sonra tarım ile uğraşmaya başlanması ile keşfedildiği bilinmektedir (Şavkay, 1990; Aktaran Güler, 1993). Osmanlı Devleti'nin içinde barındırdığı çok uluslu ve çok kültürlü yapı sayesinde ise tarhananın diğer milletlerce tanınması sağlanmıştır (Özçelik ve Özdoğan, 2007).

Tarhananın üretim yöntemi bölgeden bölgeye değişmekle birlikte, genel olarak buğday unu, yoğurt, sebze ve baharatlar yoğrulduktan sonra elde edilen hamurun birkaç gün mayalanmasiyla hazırlanmaktadır (Hayta vd., 2002; Sengun vd., 2009). Tarhana, ekşi tadı ile bilinen geleneksel fermente bir Türk ürünüdür (Blandino vd., 2003) ve bilinen en eski hazır çorbadır. Tarhana, yapılışı ve içine katılan malzemelere göre yöreden yöreye farklılık gösterse de genel olarak yaş, kuru ve çerez olarak üretimi yapılmaktadır. Bu farklılıklar yörelere ait farklı geleneksel özellikleri içinde barındırmaktadır (Çakıroğlu, 2007; Özçelik ve Özdoğan, 2007). Evlerde yapımı halen devam eden tarhananın yörelere göre farklı türlerine, yöresel ve organik pazarlar sayesinde çoğu ilde ulaşılabilmektedir.

Tarhananın ana malzemelerinden olan yoğurt, probiyotik özelliği sebebiyle bağışıklık sistemini güçlendirir (Blandino vd., 2003). İçerisinde bulunan soğan, domates, diğer bitki ve baharatlar ile 
antioksidan özellik kazanan tarhana, birçok hastalığa karşı önleyici fonksiyonel özellikler taşımaktadır. Birçok farklı yapım tekniği olması ve içeriğinin yöreden yöreye değişmesi ile de çoğu insanın damak tadına hitap edebilme özelliği gösteren bir üründür (Economidou ve Steinkraus, 1983; İbanoglu ve İbanoglu 1999 Aktaran Hayta vd., 2002). Çeşitli çalışmalarda da tarhananın yörelere göre farklılıkları, tarhana çeşitleri ve üretim yöntemleri, tarhananın tarihine dair bilgiler yer almaktadır (Özçelik ve Özdoğan, 2007; Coşkun, 2014; Altun, 2015; Başar vd., 2019; Sormaz vd., 2019).

Türk mutfağı, zengin kültürel birikimi ve Türkiye'nin sahip olduğu coğrafi konum sebebiyle birçok mutfaktan etkilenmiş ve birçok mutfağı da etkilemiştir. Özellikle tarhana gibi geleneksel, besleyici değeri yüksek bir Türk gıdasının, Dünya çapında bilinirliği artırılarak Türk Mutfağı'nın Dünya Gastronomi Turizmindeki payına katkı sağlanmış olunacaktır (Blandino vd., 2003). Tarhananın, özellikle turistik destinasyonlarda menülere dâhil edilmesi ile tanıtımının yapılmasının yanında, dünya çapında bilinirliğinin artıılması için şeflerin bilinçli olarak geliştirdikleri menülere tarhanayı dâhil etmesi önemlidir. Bunun için tarhana kullanılarak yeni ürünler geliştirilebilir, füzyon mutfak uygulamalarına dâhil edilebilir veya var olan ürünlerin inovasyonunda tarhanadan faydalanılabilir. Endüstriyel hazır çorbalara sağlıklı bir alternatif olabilecek düzeyde, kolay hazırlanma özelliğine sahip olan tarhana, sağlığa da ek fayda sağlaması açısından perakende satışlarda rekabet gücü yüksek bir ürün haline gelebilir. Tarhanaya ait görsel Resim 6'da gösterilmektedir.

\section{ZEYTINNYAĞLI YEMEKLER}

Zeytinyağı, sağlık üzerine olan birçok faydası ile diğer bitkisel yağlardan ayrılan, fonksiyonel bir üründür. Kalp sağlığını koruması, antioksidan kaynağı olması, sindirim sistemi için olumlu etkileri, vitamin açısından zengin olması, kolesterolü düşürücü etkisi ile göz ardı edilemez yararları olan bir gıdadır. Zeytinyağı, bileşiminde $\% 98$ oranla linoleik asit, oleik asit, palmitik asit gibi serbest yağ asitleri ve gliseritler ve \%2 oranla ise fenolik bileşikler, steroller, renk maddeleri ve hidrokarbonlar gibi bileşenlerden oluşmaktadır. Bu bileşenler de zeytinyağının fonksiyonel bir gıda olmasına neden olan, hastalıklara karşı sağlığı geliştirici işlevleri zeytinyağına yüklemektedir (Yorulmaz ve Tekin 2008; Bayram ve Özçelik, 2012). Günümüzde insanların sağlıklı beslenme eğilimleri, artan bilinç düzeyi ve işlenmiş ürünlere karşı daha doğal olana yönelme isteği, son dönemlerde zeytinyağına olan ilgiyi daha da yoğunlaştırmıştır (Özata ve Cömert, 2016). Bunun yanında Akdeniz bölgesinin beslenme şeklini belirleyen zeytinyağlı yemekler, sağlıklı bir beslenme alışkanlığına da ismini vermiştir (Visioli vd., 2018). Akdeniz tipi beslenme denilen diyette, günlük besin ihtiyacının bitki bazlı gıdalar, balık ve özellikle zeytinyağ 1 tüketilerek karşılandığı ve bu yönüyle günlük dengeli ve yeterli beslenme koşullarının sağlandığ bilinmektedir. Bu doğrultuda yapılan çalışmalar da bölgenin beslenme alışkanlıklarının oldukça sağlıklı olduğunu ortaya koymuştur (Barbaros ve Kabaran, 2014). Özellikle Akdeniz ve Ege bölgelerinde sıklıkla kullanılan zeytinyağı, Türk mutfağında kahvaltılarda, öğle ve akşam yemeklerinde tercih edilmektedir. Bunun yanında, zeytinyağlı yemekler Türk mutfak kültüründe önemli bir yer tutmaktadır. Kabakçiçeği dolması, zeytinyağlı enginar, börülce salatası, maş piyazı, geren kavurması, fasulye ekşilemesi, Alaşehir kapaması, yaprak sarması, Erdek havyarı zeytinyağı ile yapılan yöresel yemeklere örnek olarak verilebilir. Tüm bu yemeklerin malzemeleri incelendiğinde sızma zeytinyağı yanında, lifli ve posalı sebzeler, baklagiller ve kolesterol oranı düşük, proteince zengin gıdaların varlığı dikkat çekmektedir. Marmara Bölgesinden başlayarak Güneydoğu Anadolu Bölgesine kadar birçok şehrin zeytin yetiştiriciliğine uygun olması ile Türkiye, zeytin yetiştiriciliği için oldukça geniş bir coğrafyaya sahiptir (Durlu Özkaya vd., 2018). Zeytin yetiştiriciliği yapılan bu bölgelerde ağırlıklı olarak 
zeytinyağı tüketimi söz konusu olduğu düşünüldüğünde, Türk mutfağının önemli bir kısmının Zeytinyağlı yemeklerden oluştuğu görülmektedir. Zeytinyağlı yemek örneklerine ait görseller Resim 8'de gösterilmektedir.

\section{MERCIMEK KÖFTESİ}

Ana malzemeleri kırmızı mercimek, köftelik bulgur, yeşil soğan ve maydanoz olan mercimek köftesi, Türk kültüründe 5 çayı, özel gün yemekleri gibi etkinliklerde sunulan, özellikle Türk misafirperverliğinin önemini sembolize eden yiyeceklerden biridir. Mercimek köftesi, Amerikan Kanser Araştırmaları Enstitüsü'nde (AICR) yapılan araştırmalar neticesinde, Dünya'da kanserle savaşan 7 gida arasına girmeyi başarmıştır. Mercimek köftesinin ana malzemelerinden olan kırmızı mercimek, protein açısından oldukça zengin, bulgur ise lifçe zengin bir tam tahıl olması ile kolorektal kanser riskini azaltmaktadır (American Institute for Cancer Research, 2015). Ayrıca mercimek köftesi yapımında kullanılan maydanoz, yeşil soğan ve limon gibi sebzeler sayesinde $C$ vitamini açısından zengindir ve antioksidan özelliktedir. $C$ vitamini, vücut direncini korumaya yardımcı, kemik ve diş sağlığında etkili bir vitamindir ve mercimek köftesi yapılırken bu gıdalar çiğ olarak eklendiği için vitamin kaybına da uğramadan vücuda alınmış olur (Bulduk, 2018). Mercimek köftesinin tüketimi sadece 5 çayı menüleriyle sınırlı kalmamalı, farklı sunum teknikleriyle turistik destinasyonlarda otel ve restoran menülerinde yer almalıdır. Şefler ve aşı̧ılar aracılığıyla uluslararası fuarlarda sağlık için önemi vurgulanarak tanıtımının yapılması gereklidir. Özellikle, mercimek köftesinin antikanser yiyecekler arasına seçilmesi, yöresel yiyeceklerin pazarlama faaliyetlerine katkıda bulunacak bir adımdır ve bu adımın değerlendirilmesi yine yiyecek içecek sektörü çalışanlarına düşmektedir. Mercimek köftesine ait görsel Resim 9'da gösterilmektedir.

\section{VAN OTLU PEYNİRI}

Doğu Anadolu Bölgesine özgü yöresel bir gıda olan otlu peynir, 30 çeşit bitki içermektedir. Otlu peynirin çok eskiden şifa verici özelliği keşfedildiğinden, ilaç olarak kullanılmak üzere üretildiği bilinmektedir. Daha sonraları ise, tüketimi yaygınlaştıkça üretimi de artmış, günün en önemli öğünlerinden olan kahvaltı sofralarında yerini almıştır (Özçelik, 2015). Çĭg koyun sütü kullanılarak üretilen peynir, sütün mayalanması sonrası oluşan pıhtının süzülmesi, otların peynire eklenmesi, peynir karışımının torbalara doldurulması, baskılama ve kalıplar halinde kesme işlemleri gibi birçok aşamadan geçmektedir. Olgunlaştırma için sıkıştırılarak bidonlara yerleştirilen peynirler, 3 ila 7 ay arasında olmak üzere toprağın altında bekletilerek hazırlanmaktadır (T.C. Tarım ve Orman Bakanlığı, 2018). Önceleri sadece yöre halkının ürettiği peynir, artık endüstriyel olarak da üretilmekte ve Türkiye'nin çeşitli illerine satışı yapılmaktadır. Van otlu peynirinin en önemli özelliği, içeriğinde kullanılan otların ve baharatların Van ilinde doğadan özel olarak seçilip toplanmış olmasıdır. İçeriğinde bulunan otlar ve baharatlar sadece tat ve aroma vermeyip, aynı zamanda antimikrobiyel ve antioksidan etki göstererek ürünün raf ömrünü artırmaktadır (Tunçtürk vd., 2014). Otlu peynir; çöven otu, tarakotu, dereotu, çiriş otu gibi şifalı olarak bilinen bitkiler içermesi ile üriner sistem enfeksiyonları ve kalp hastalıklarına karşı koruyucu etki göstermektedir. Bununla birlikte, farklı türde otlar içermesi ile yüksek C vitamini içeriğine sahip, fonksiyonel bir gıdadır. Van kahvaltı sofrasının gastronomi turizmi için önemi bulunmakta ve ilin diğer çekici özellikleri ile önemli bir turistik destinasyon olduğu bilinmektedir. Otlu peynir gibi, gıdaların fonksiyonel özelliklerinin bulunması da turistik çekiciliği daha çok artırmaktadır (Özçelik, 2015). Zağralı ve Akbaba (2015); Aydoğdu ve Duman (2017); Çatır ve Ay (2018) yaptıkları çalışmada, destinasyonların çekicilik unsurları olarak yöresel 
yiyeceklerin rolünü belirtmiş ve önemi üzerinde durmuştur. Bir yöreye özgü çekicilik oluşturan yerel gıdalar, turistlerin destinasyon seçimlerinde etkili olmaktadır. Ancak, yerel gidaların ve yemeklerin tanıtımındaki olumsuzluklar veya eksiklikler yörelerin tanıtımı, tercih edilmeleri ve yerel kalkınma düzeylerini olumsuz etkilemektedir (Türkay ve Genç, 2017). Van otlu peynire ait görsel Resim 10'da gösterilmektedir.

\section{MAVIYEMIŞ}

Dünyada yaban mersini ve blueberry, ülkemizde ise maviyemiş olarak bilinen mavi, üzümsü bir meyvedir (Resim 11). Meyvenin farklı formları, Karadeniz bölgesinin çeşitli illerinde, kendiliğinden, doğal olarak yetişmektedir. Ayrıca, ülkemizin çeşitli illerinde çalı çileği, ayı üzümü, ligarba gibi farklı şekillerde isimlendirildiği de bilinmektedir. Maviyemişin bazı yabani formlarının anavatanının Doğu Karadeniz Bölgesi olduğu ve bahçe bitkisi olarak yetiştirilen birçok türe göre antioksidan özelliği en fazla olan meyve olduğu bilinmektedir. Maviyemiş, adeta bir fitokimyasal deposudur. Bu bakımdan antikanserojen, antimikrobiyal, antioksidan, prebiyotik, kalp sağlığını koruyucu özellikte fonksiyonel bir gıdadır. Maviyemişin; obezite, diyabet, tümör oluşumu, enfeksiyon, bilişsel gerileme ve kemik erimesi gibi hastalıkları hafifletici etkisi bilimsel olarak kanıtlanmıştır. Sağlıklı yaşlanmayı desteklemesi ve kanser riskini azaltmasının yanında patojen mikroorganizmaları yok etmesi açısından da oldukça önemli bir meyvedir (Patel, 2014). Fonksiyonel bir gıda olan maviyemişin, sağlı̆̆ı destekleyici etkilerinden bir tanesi de kan şekerini düşürücü özellikte olmasıdır. Bu özelliği ile tatlandırıcı olarak kullanılabilme potansiyeli ile şeker hastaları için oldukça fayda sağlayacak bir gıdadır (Orman Genel Müdürlüğü (OGM), 2015).

Mutfakta son dönemde sağlığa olan yararının bilinirliğinin artması ile daha çok kullanım alanı bulmaya başlamıştır. Ana yemeklerde garnitür olarak, ana malzeme veya sos yapımında kullanımının yanında; reçel sanayisinde, çeşitli süt ürünlerinde, unlu mamuller ve içecek sektörü de dahil olmak üzere çok geniş bir kullanım alanına sahip bir meyvedir. Gıda sektörü dışında ise, cilt bakım ürünleri ve ilaç sektöründe kullanılan maviyemiş, yerel üreticilerin desteklenmesi ile, ülke ekonomisine katkıda bulunma potansiyeli oldukça yüksek bir üründür. Ancak çoğunlukla yaban mersini veya blueberry olarak bilinen maviyemişin yurtdışı menşeili bir ürün olarak tanınması ve ülkemizde doğal olarak yetiştiğine dair bilginin yeterince yerleşmemesi önemli bir problemdir. Ülkemizde, özellikle Doğu Karadeniz Bölgesinde yetişen türlerin islah çalışmalarının yapılması ve piyasada geleneksel bir ürün olarak yer alması elzemdir. Bu durum, aynı zamanda Türk Gastronomisine de değer kazandıracak bir unsurdur (Patel, 2014; OGM, 2015). Meyvenin maviyemiş ismi ile tanıtım ve pazarlamasının artırılması ve mutfaklarda kullanımının yaygınlaştırılması sağlanarak Doğu Karadeniz bölgesinde gerçekleştirilen turizm türlerine ek olarak gastronomi turizminin de bu yönden ön plana çıkmasına katkı sağlanacaktır. Böylelikle dünyanın her bölgesinden gelecek gastronomi tutkunları için, bir turizm kapısının daha aralanması açısından oldukça önemli bir yerinin olduğu düşünülmektedir (T.C. Devlet Planlama Teşkilatı Müsteşarlığı ve Japonya Uluslararası İş Birliği Ajansı, 2004; Yavuz, 2005).

\section{TÜRK KAHVESI}

Kahvenin ortaya çıkmasına dair, sözlü kültürde anlatılan birçok hikâye vardır. Bu hikâyelerin biri, kasabanın birinde yaşayan halkın bilinmeyen bir hastalığa yakalandığını gören $\mathrm{Hz}$. Süleyman'ın Yemenden gelen kahve çekirdekleri ile hazırladığı içecek sayesinde hastaları iyileştirdiği ve bu şekilde kahveyi ilk keşfeden kişi olduğudur. Diğer bir hikâyeye göre ise Yemenli keçi çobanı olan Kaldi, bir ağacın yapraklarını yedikten sonra keçilerinde bir hareketlilik 
gözlemlemiş, yorgunluğunu gidermek ve aynı canlılığa sahip olabilmek için o ağacın meyvelerini kaynatarak suyunu içmiş ve bu bilginin yayılmasını sağlamıştır (Tez, 2018).

Kahve, ülkemize 16. yüzyılda Osmanlı döneminde gelmiştir. İlk zamanlar kahve tüketimi çok küçük bir kesim tarafından gerçekleşse de sonraları yaygınlaşmıştır. Özellikle kahve yapılış şekli ve servisine çok önem verilmeye başlanmıştır. Öyle ki padişahların kahvesi, İstanbul'un Eyüp ilçesinde bulunan Gümüşsuyu'ndan özel olarak getirilen su ile yapılmıştır (Gürsoy, 2005 Aktaran Bulduk ve Süren, 2015). Daha sonraları yaygınlaşan kahve ritüelleri, 1554 yılında Tahtakale'de ilk kahvehanenin açılmasıyla oluşmuştur (Kaplan, 2011). Kahvehanelerin açılması ile Türk kahvesi sadece bir içecek olmaktan çıkmış, insanların bir araya geldiği, sohbet ettiği, arkadaşlıklar kurduğu ve eğlendiği bir mekânın ana bileşeni haline gelmiştir. Türk kahvesi, insanları sosyalleştirmesi yanında, Türk geleneklerini ve misafirperverliğini sembolize eden bir kültür ögesi halini almıştır (T.C Kültür ve Turizm Bakanlığı, 2013). Avrupa ülkelerinde kahve, Osmanlı Devleti sayesinde 17. yüzyılda tanınmıştır (Kömeçoğlu, 2009; Aktaran Kaplan, 2011). Anavatanı Türkiye olmamasına rağmen, Türk kültürü, gelenek ve görenekleri, örf ve adetleri ile bütünleşmiş ve geleneksel bir içecek haline gelmiştir. Köpügüu, telvesi, hazırlanışı, ağır ateşte pişirilmesi ve servisi ile özel bir kahve çeşidi olan Türk kahvesi ile kahve kültürü Dünya'da Türkler aracılığıyla gelişmiştir. Bu nedenle ülkemizi tanıtan turistik bir değer taşımaktadır. 2013 yılında UNESCO Somut Olmayan Kültürel Miraslar listesine alınan Türk kahvesinin her gün tüketilmesi sağlık için de faydalar teşkil etmektedir (T.C Kültür ve Turizm Bakanlığı, 2013). Sindirim sistemini rahatlatıcı, zihni güçlendirici, kalp sağlı̆̆ını geliştirici özellikleri ile fonksiyonel özellikte bir içecektir (Küçükkömürler ve Özgen, 2009). Bunlarla birlikte ortalama düzeyde kahve tüketen kişilerde Tip 2 diyabet riskinin azaldığ 1 da bilinmektedir (Ertaş ve Akbulut, 2013). Niasin, potasyum ve magnezyum açısından zengin içeriğe sahip olan kahvenin aynı zamanda kardiyovasküler hastalıklar için önleyici fonksiyon üstlendiği de belirtilmektedir (Wu vd., 2009; Erdoğan ve Oğuz, 2016). Türk kahvesine ait görsel Resim 11'de gösterilmektedir.

\section{TOKAT YAPRAĞI}

Asma yaprağı yetiştiriciliği Türkiye'de çok köklü bir geçmişe sahiptir ve Dünya' da bulunan asma yaprağ gen merkezlerinden birisinin de Türkiye olduğu bilinmektedir (Gülcü 2012). Ülkede hemen hemen her bölgede yetiştiriciliğinin yapılmasına rağmen ticari olarak daha çok Tokat ilinin Erbaa ilçesi en büyük üretim payına sahiptir (Kara ve Akın, 2011). Asma yapraklarının (Resim 12) kalsiyum, fosfor, vitamin ve diyet lifi içeriği ile sağlık üzerinde olumlu etkileri bulunmakta ve fonksiyonel gıda olarak değerlendirilmektedir. Tokat'ın Erbaa ilçesinde üretilen Narince bağı asma yaprağı coğrafi işaret alarak tescillenmiştir. Narince bağı üzümlerinin şarap yapımında önemli bir yeri olduğu bilinmesine rağmen bu bağın asma yaprakları da oldukça kaliteli, ince damarlı olması sebebi ile şaraplık üzüm yerine yaprakları için yetiştiricilik yapıldığı da dikkati çekmektedir (Cangi ve Yağcl, 2017). Zeytinyağlı yemeklerin başında gelen yaprak sarmasının Türk mutfak kültüründe oldukça önemli bir yere sahip olduğu bilinmektedir. Tokat yöresine özgü Bat isimli yemeğin servis edilmesinde kullanılması ile asma yaprağı, yöresel yemek kültürünün bir simgesi haline gelmiştir. Yavan dolma, erikli yavan dolma, bakla dolması da Tokat iline özgü asma yaprağından yapılan diğer yöresel yemeklerdendir (T.C. Kültür ve Turizm Bakanlığı, 2019). Fonksiyonel gıda olarak bilinen yaprağın, C vitamini kaybına uğramaması için çiğ olarak salata ve mezelere eklenerek tüketilmesinde fayda vardır (Sayın, 2010). Yerel ekonomilerin canlanması adına bu yemeklerin ve bağcılık kültürünün öneminin vurgulanması için yiyecek içecek işletmelerinde şeflere büyük sorumluluklar düşmektedir. Tanıtımının yapılması ve yöresel yemeklerin bilinirliğinin artırılması için Tokat yaprağına menülerde yer verilerek bölgesel turizm faaliyetlerine katkı sağlanabilir. 


\section{SIYYEZ BUĞDAYI}

Buğdayın atası olarak bilinen siyez buğdayı, 12 bin yıldır varlı̆̆ını sürdürmektedir. Günümüzde Kastamonu ilindeki birçok üretici, Latince adiyla triticum monococcum'un einkorn olarak bilinen en eski buğday türü olan Siyez'i yetiştirmeye devam etmektedir. Buğday taneleri, düşük miktarda gluten ve yüksek protein içeriğine (yaklaşık \%20) bağlı olarak geleneksel çeşitlerden farklı fonksiyonel özellikler göstermektedir. İçerisinde diğer buğday çeşitlerine göre daha yüksek protein, karotenoid, manganez, kükürt ve kalsiyum gibi mineraller bulunmaktadır (Slow Food Foundation, 2018). Bununla birlikte diğer ekmeklik buğdaylara göre daha fazla çinko, demir ve bakır içermesi gibi sağlı̆̆ı geliştirici özelliklerine rağmen ürünün kârlı görülmemesinden dolayı yetiştirilmesi günden güne azalmaktadır. (Suchowilska vd., 2012; Dorofeev vd., 1987 Aktaran Zaharieva ve Monnoveux, 2014). Siyez buğdayı uzun bir bitkisel döngüye sahiptir ve genellikle kötü hasat koşullarında üretimi gerçekleştirilmektedir. Buna rağmen, diğer hibrid türlerin üretilemediği soğuk iklim koşullarında yetişebildiği için halen Kastamonu'da üretimi yapılmaktadır (Slow Food Foundation, 2018). Yerel halk, siyez buğdayını çoğunlukla bulgur olarak değerlendirmektedir. Siyez buğdayı aynı zamanda, Slow Food Manifestosunun Presidium projesine Türkiye'den dâhil edilen ilk üç ürün arasındadır. Bu proje ile Dünya'da tükenmekte olan yerel tür ve bitki çeşitliliği, belirli bölgelere has ürünler, geleneksel üretim yöntemleri ve yerel üreticiler desteklenmektedir. Aynı zamanda bu ürünlerin dünya pazarına sunulmasına imkân sağlayarak yerel ürünlerin yok olmasını engelleyen, sürdürülebilir bir projedir (Slow Food Foundation, 2018). Türk mutfağında siyez bulguru genellikle ekşili bulgur pilavı olarak değerlendirilir ve tereyağında sotelenmiş soğan ile birlikte et suyunda pişirilerek servis edilmektedir. Ayrıca siyez buğdayının; un, ekmek, ezme, erişte ve tarhana üretiminde de kullanıldığı bilinmektedir (T.C. Kastamonu Valiliği, 2016). Türk mutfağında kullanımı ile ilgili bilgilerin geniş kitleye yayılması için ilgili kurumların pazarlama ve satış faaliyetlerini geliştirecek çalışmalar yapması gereklidir. Kastamonu'da yılın ilk hasadından sonra siyezin tanıtımı için festival düzenlendiği bilinmektedir. Ancak yeterli gelmediği de pazarlama sorunları olmasından anlaşılacağı üzere aşikardır. İnsanların sağlıklı beslenme yönünde daha çok bilinç kazanması ve günlük diyetlerini buna göre şekillendirmesi üzerine üretim alanlarını genişleten Kastamonulu üreticiler de Kastamonu'da Coğrafi işaret alan buğdayın atası Siyez için, satış ve pazarlama faaliyetlerinin kısıtlı olmasından şikâyet etmektedirler (www.turkpatent.gov.tr; www.sozcu.com.tr). Siyez buğdayına ait görsel Resim $13^{\prime}$ te gösterilmektedir.

\section{BOĞATEPE GRAVYERI}

1877-78 Osmanlı-Rus Savaşı'nın sonunda, Rus Çarlığı tarafından Kars ve civarının sömürgeleştirilmesini kolaylaştırmak için uzak bölgelerden gelen nüfusun bölgeye yerleşmesi teşvik edilmiştir. Bu durumun neticesi olarak, İsviçreli ve Alman toplulukları Kars ve çevresine yerleşerek; alışkanlıklarını, geleneklerini ve özellikle de peynir yapım sanatını bölgeye taşımasıyla bölgede peynir üretimi başlamıştır (Slow Food Foundation, 2015; Arınç, 2018). Günümüzde ise Boğatepe yaylalarında halen aynı gravyer peynir yapım tekniği sürdürülmektedir (Slow Food Foundation, 2015). Oldukça uzun ve meşakkatli bir üretim süreci bulunan gravyer peynirleri en az 6 ay boyunca depolarda bekletilerek üretilmektedir. Boğatepe gravyeri Presidium projesine Türkiye'den dâhil edilen ürünlerden bir diğeridir. İsviçre'de üretilen gravyer peynirine kıyasla fermantasyon ve gözenek oluşumu için gerekli olan bakteri kültürleri (Propionibacterium) doğal ortamdan sağlanarak, aşılanmadan ürüne geçmektedir. Peynirde özel aromanın gelişmesi için kaliteli bir süt kaynağı ve uygun ortam sıcaklığı gerekmektedir. Bunun sağlanması için de büyükbaş hayvancılığın gelişmiş olduğu yörede 1800 m'den yüksek alanlarda farklı bitki çeşitleri ile beslenen hayvanlardan elde edilen süt oldukça 
niteliklidir (Topuk, 2014; Arınç, 2018). Kars gravyerine özgü, doğal ortamda bulunan bu bakteriler sayesinde peynir, sindirim ve bağışıklık sistemi için oldukça faydalı bir gıda haline gelmekte ve bu işlevi ile yemeklerden sonra adeta sindirime yardımcı takviye bir gıda olarak tüketilmektedir (Slow Food Foundation, 2015; Arınç, 2018). Ayrıca fosfor ve kalsiyum açısından da zengin olması yönüyle fonksiyonel özellikler göstermektedir. 100 gram gravyer peynirinin 605 $\mathrm{mg}$ fosfor içeriğine sahip olduğu ve günlük kalsiyum ihtiyacının tamamını, fosfor ihtiyacının ise yaklaşık olarak yarısını karşıladığı bilinmektedir (Kavas vd., 2006). Bu ender bulunan peynir türü, yerel kalkınmaya fayda sağlamakta ve bölgenin gelişmişlik düzeyinin artırılması için gastronomik bir unsur olarak turizm potansiyeli yaratmaktadır. Ancak bu peynir türünün değerinin yeterince bilinmemesi, üretimini yapan işletmelerin sayısının oldukça sınırlı olması ve pazarlama faaliyetlerinin kisitlı düzeyde olması, var olan turizm potansiyelini olumsuz etkilemektedir (Arınç, 2018). Gastronomi rotaları adı altında Boğatepe Köyü ve bölgedeki peynir müzesi olan Zavot Eko Müzesi'nin gastro turistler için tanıtıcı faaliyetlerde kullanımının artırılması gerekmektedir. Böylelikle, bölgede üretilen peynir çeşitlerinin değeri hem yerel halk hem de turistler için bir farkındalık oluşturacağı gibi yerel kalkınmaya destek olacak ve bölgenin gastronomi turizmine katkı sağlayacaktır (www.yolculukterapisi.com). Boğatepe gravyeri Resim $14^{\prime}$ te gösterilmektedir.

Resim 1: Yoğurt

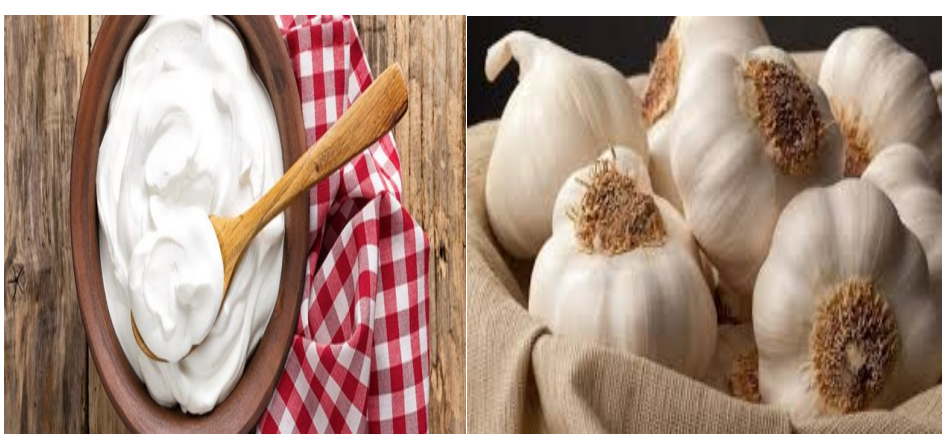

Resim 3: Siyak Sarımsak

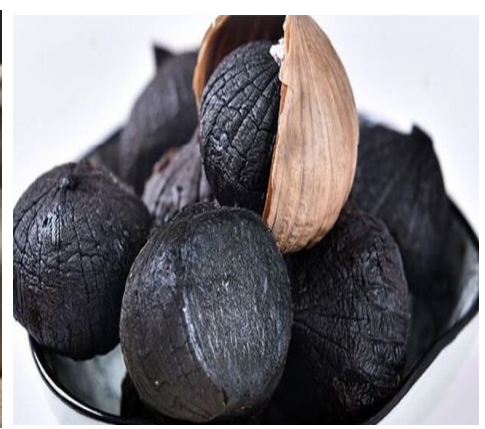

Kaynak: (www.ntv.com.tr) Kaynak: (www.saglampatent.com.tr) Kaynak: (www.aydin24haber.com)

Resim 4: Şalgam Suyu

Resim 5: Kefir

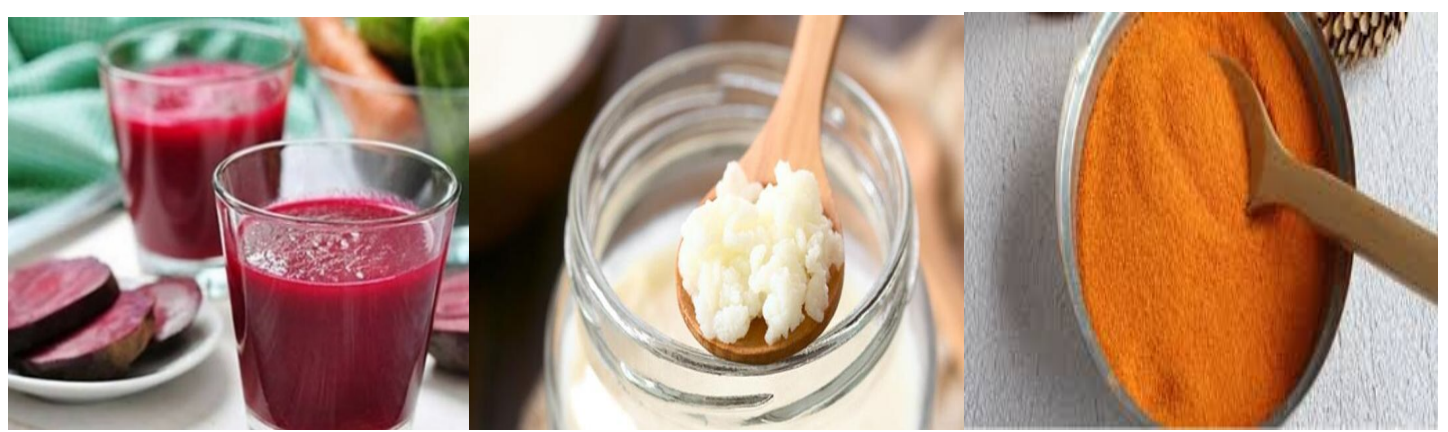

Kaynak: (www.star.com.tr) Kaynak: (www.hurriyet.com.tr) Kaynak: (www.kisikates.com.tr) 
Resim 7: Zeytinyağlı Yemekler
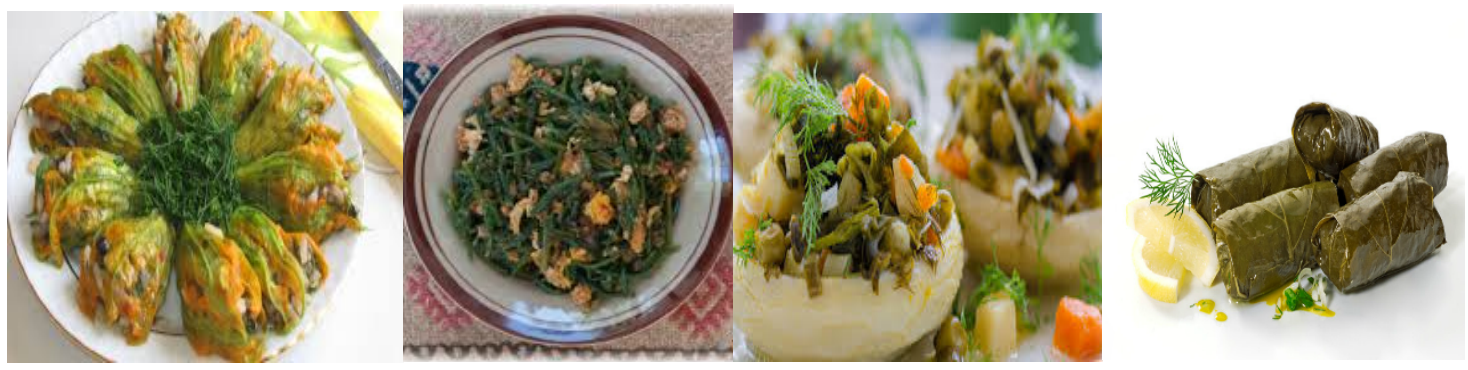

Kaynak: (www.vakifzeytinleri.gov.tr; www.kulturportali.gov.tr; tr.pinterest.com; www.hurriyet.com.tr)

Resim 8: Mercimek Köftesi Resim 9: Otlu Peynir Resim 10: Maviyemiş
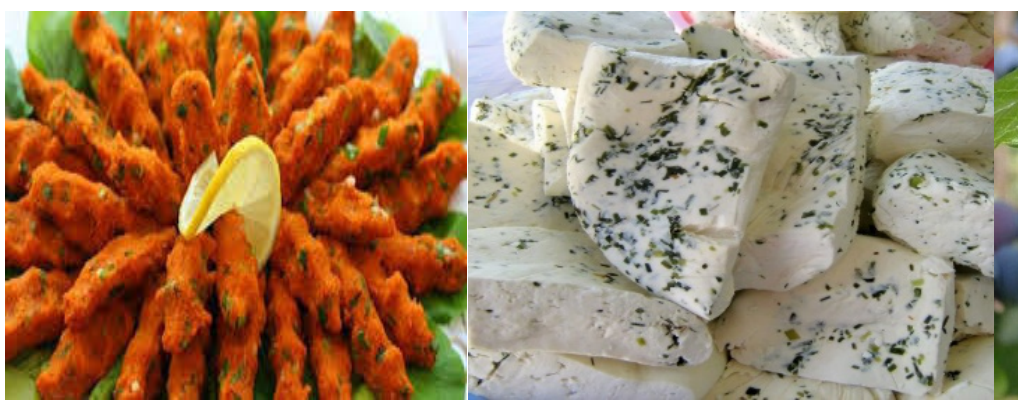

Kaynak: (https://www.sabah.com.tr;) Kaynak: (van.ktb.gov.tr) Kaynak: (apelasyon.com)

Resim 11: Türk Kahvesi

Resim 12: Tokat Asma Yaprağı Resim 13: Siyez Buğdayı

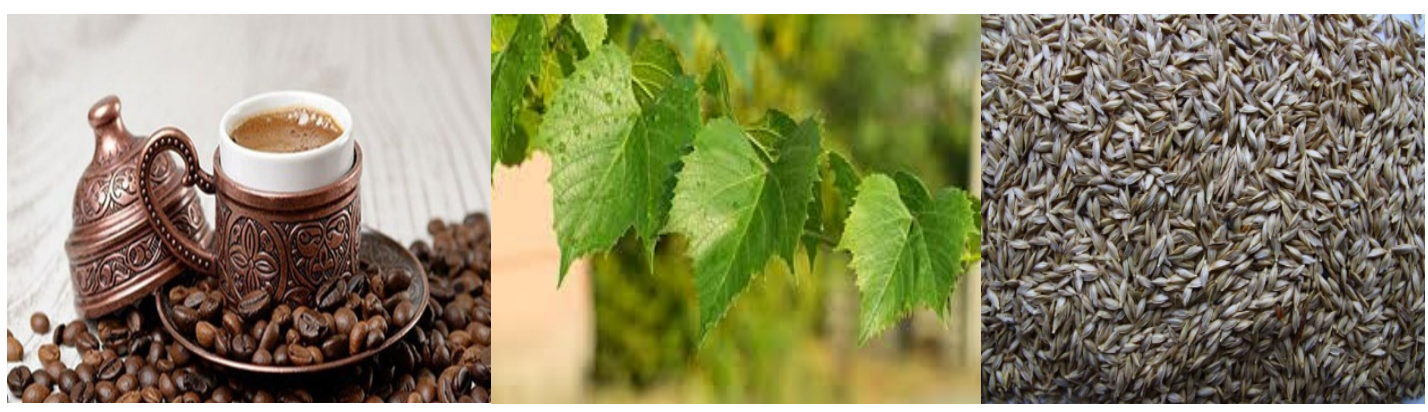

Kaynak: (www.gidagundemi.com) Kaynak: (www.tokat.com) Kaynak: (www.siyezun.com)

Resim 14: Boğatepe Gravyeri

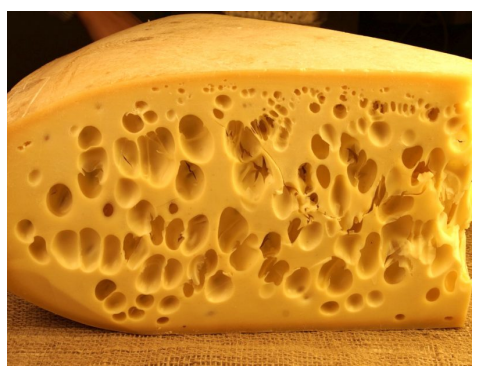

Kaynak: (http://koculupeynircilik.com) 


\section{SONUÇ VE ÖNERILER}

Bazı hastalıkların tedavi edilememesi, nedenlerinin ortaya koyulamaması ve hastalıkların her geçen gün daha çok çeşitlenerek artması, insanları daha sağlıklı beslenme arayışına sokmaktadır. Fonksiyonel gıdalara olan talebe karşılık olarak yiyecek içecek endüstrisinin sağlıklı beslenme eğilimine cevap vermesi turizm sektörü için oldukça önemli görülmektedir. Günümüzde insanların yeni yemek, yeni mutfak ve yeni tatlar arayışının fonksiyonel gıdalarla karşılık bulması, bu yeni trende öncülük ederek gastronomi turizmine katkı sağlayacağı düşünülmektedir. Özellikle alternatif turizm çeşitleri ile bölgelerin kalkınması, henüz keşfedilmemiş veya tanınırlığı yeterli seviyeye ulaşmamış yöresel gıdaların menülerde kullanımının artırılması ve turizm sektöründe pazarlanmasının etkili bir şekilde yapılması önem arz etmektedir. Restoran işletmeciliği ve otelcilik gibi turizm faaliyetlerinin yoğun olarak gerçekleştirildiği yiyecek içecek sektörlerinde, yöresel gıdaların kullanımı hakkında şeflere büyük bir görev düşmektedir. Menülerde yer alan yemeklerin üretimi için ithal malzeme kullanımı yerine, ülkemize özgü gıdaların kullanımı desteklenerek, bu bölgelerin yerel kalkınması ve turistik faaliyetlerin canlandırılmasına katkıda bulunulması açısından çok önemlidir.

Gıdaların fonksiyonel özellikleri hakkında şeflerin bilinçlendirilmesi ile menülerin düzenlenmesi ve yeni tariflerin geliştirilmesi ile gıdalara karşı olan güvensizlik ve tehdit algısının yerine, gıdaların sağlık kaynağı olarak görülmesi sağlanabilir. Mutfakta yeni bir trend olarak, yapay zekâ teknolojileri ve nesnelerin interneti gibi teknolojide gerçekleşen yeniliklerin yiyecek içecek işletmelerinde uygulanması, kişiye özel fonksiyonel özellikli menüler geliştirilmesi gibi yenilikler tasarlanarak, yeni ve eşsiz bir gastronomik deneyimin elde edilebileceği ve günümüzde büyümeye devam eden gastronomi turizmine ve Türk Gastronomisine oldukça katkısı olacağ düşünülmektedir.

Tüketiciler için gıdaların bilinmeyen fonksiyonel özellikleri ile ilgili tanıtımlar, bilgilendirici broşürler, menülerde kısaca gıdaların fonksiyonel özelliklerinin vurgulanması sağlanabilir. Restoran, otel, catering gibi yemek hizmeti veren sektörlerde şeflerin fonksiyonel gıdaları bilinçli olarak kullanmaları ve menülerde bu içeriklerin vurgulanması sağlanmalıdır. Bu bilgilerin menülere işlenmesi ve yerleştirilmesi konusunda menü mühendisliğinden faydalanılarak, menülerde doğru konumlandırılması ve uygulanması sonucu, menü analizinin yapılmasında kolaylık sağlayacaktır.

Çalışmada bahsedilen fonksiyonel gıdaların pazar payının geliştirilmesi ve üreticilerin desteklenmesi, satış faaliyetlerinin artırılması, daha çok tüketiciye ulaşılması üretim yapılan illerin kalkınmasına ve Türkiye ekonomisine de önemli katkılar sağlayacaktır. Kastamonu siyez buğdayı, Boğatepe gravyeri, maviyemiş gibi ülkede yetişen veya üretilen kaliteli ve türdeşlerine göre üstün özelliklere sahip, fonksiyonel ürünlerin hak ettiği değeri bulamaması Türk gastronomisi için üzücü bir durumdur. Bu konuda yapılacak festivaller, kongreler gibi tanitıcı faaliyetlerin; sivil toplum kuruluşları, akademisyenler, yiyecek içecek işletmeleri ve üreticiler ile iş birliği içerisinde gerçekleştirilmesi adına yapılacak organizasyonlara ağırlık verilmelidir.

Gastro turistler için bir bölgenin veya yörenin yöresel yemeklerinin en çok çekiciliğe sahip olan unsur olduğu göz önüne alınırsa, bölgede yöresel yiyeceklere ve bu ürünlerin satışı yapılan mekanlara ulaşılabilirlik ve fiyat, destinasyonun pazarlanmasında önemli faktörler olarak ilk sırada yer almaktadır. Ürünlerin tercih edilmesindeki diğer önemli faktörler olan gıda güvenliği ve hijyen standartlarının yerine getirilmesi hususuna dikkat edilmelidir. Üretimin ilk aşamasından tüketiciye ulaşana dek, zincirdeki tüm aşamaların güvenliği ve hijyeni sağlanmalıdır. 
Ürün pazarlamasında görülen yetersizlikler için, günümüzde önem kazanan ve milyonlarca takipçisi olan sosyal medya kanallarında aktif rol üstlenilmesi ve başarılı sosyal medya pazarlaması örneklerinin takip edilmesi ile farklı pazarlama çeşitleri kullanılması, fayda sağlayacak çözümlerden bir tanesidir.

Türk mutfağının içinde barındırdığı zengin kültürel birikim, hâkim olduğu geniş coğrafya ile etkilendiği ve etkilediği mutfaklar ve ürün çeşitliliği göz önünde bulundurulduğunda bu konuda yapılacak çalışmaların gastronomi turizminin gelişimine oldukça katkı sağlayacağı düşünülmektedir. Ayrıca bu araştırmanın devamı niteliğinde, belirli işletmeler ile ortak bir çalışma yürütülerek, yiyecek ve içeceklerin fonksiyonel özelliklerine göre sinıflandırıldığı ve günümüzde beslenme sorunlarından kaynaklı, yaygın olarak görülen hastalıklara özgü yemek önerilerinin bulunduğu bir menü tasarlanarak, tüketicilerin bu menüye dair görüş ve önerilerinin değerlendirildiği bir çalışma yapılabilir. Bir diğer çalışma önerisi olarak, Türk mutfağına ait yöresel yemeklerin içeriğindeki fonksiyonel gıda varlığının araştırılması düşünülebilir.

\section{KAYNAKÇA}

Aghatabay, N.M. (2005). Keyf-i Kefir, Kimya Teknolojileri, 58: 64-65.

Akan, S. (2014). Sarımsak (Allium sativum L.) Tüketiminin İnsan Sağlığına Yararları, Akademik Gıda, 12(2): 95-100.

Alıç, H. ve Ceyhan, N. (2012). Bağırsak Mikroflorası ve Probiyotikler, Türk Bilimsel Derlemeler Dergisi, 5(1): 107-113.

Altun, İ. (2015). Kahramanmaraş-Elbistan'da Geleneksel Olarak Yapılan Tarhana ve Tarhana Çorbası, Ĭgdır Üniversitesi Fen Bilimleri Enstitüsü Dergisi, 5(1): 45-49.

American Institute for Cancer Research (2015). 7 Cancer-Fighting Foods From Around the World. [Online] http://www.aicr.org/enews/2015/10-october/enews-7-cancer-fighting-foods-fromaround-world.html [Erişim Tarihi: 31.08.2018].

Arınç, K. (2018). Boğatepe Köyü'nde Gravyer Peyniri Üretimi ve Sürdürülebilir Gelişme Bakımından Önemi (Kars/Türkiye), Türk Coğrafya Dergisi, 70: 7-18.

Avcı, G. ve Erdoğan, S. M. (2017). Tiroit Fonksiyon Bozukluğunda Fonksiyonel Besinlerin Etkinliği, Kocatepe Veterinary Journal, 10(4): 331-336.

Ayaz, E. ve Alpsoy, H.C. (2007). Sarımsak (Allium sativum) ve Geleneksel Tedavide Kullanımı, Türkiye Parazitoloji Dergisi, 31(2): 145-149.

Aydoğdu, A. ve Duman, S. (2017). Destinasyon Çekicilik Unsuru Olarak Gastronomi Turizmi: Kastamonu Örneği, Turizm ve Araştırma Dergisi, 6(1): 4-23.

Bağıran Özşeker, D. (2017). Fonksiyonel Gıdalar, (Editör) Kurgun, H.: Gastronomi Trendleri içinde (ss. 151-177) Ankara: Detay Yayıncilık.

Balçık Mısır, G. (2012). Denizel Kaynaklı Bazı Fonksiyonel Gıdalar ve Gıda Bileşenleri, Yunus Araştırma Bülteni, (1):1-7.

Barbaros, B. ve Kabaran, S. (2014). Akdeniz Diyeti ve Sağlığı Koruyucu Etkileri, Beslenme ve Diyet Dergisi, 42(2): 140-147.

Başar, F., Şen, N., Silahşör, Y. ve Başar, B. (2019). Erzincan Yöresel Mutfak Kültürü Unsuru Olan Tarhananın Gastronomi Turizmi Açısından Değerlendirilmesi, Journal of Gastronomy Studies, 7 (1): 328-339. 
Bayram, B. ve Özçelik, B. (2012). Zeytinyağının Biyoaktif Bileşenleri ve Sağlık Üzerine Yararları, Akademik Gıda, 10(1): 77-84.

Blandino, A. Alaseeri, M.E., Pandiella, S.S., Cantero, D. and Webb, C. (2003). Cereal Based Fermented Foodsand Beverages, Food Research International, 36: 527-543.

Bulduk, S. (2018). Beslenme Illkeleri ve Mönü Planlama. (4. Basım), Ankara: Detay Yayıncılık.

Bulduk, S. ve Süren, T. (2008). Türk Mutfak Kültüründe Kahve, ICANAS 39. Uluslararası Asya ve Kuzey Afrika Çalışmaları Kongresi, Ankara.

Canbolat, E. (2017). Sarımsağın Besinsel Yönden ve Sağlık Açısından Değerlendirilmesi, Uluslararası Taşköprü Pompeipolis Bilim Kültür Sanat Araştırmaları Sempozyumu, Kastamonu Üniversitesi 10 -12 Nisan 2017. Kastamonu. ss: 935-949.

Cangi, R.ve Yağcl, A. (2017). Bağdan Sofraya Yemeklik Asma Yaprak Üretimi, Nevşehir Bilim ve Teknoloji Dergisi, 6: 137-148.

Cencic, A. and Chingwaru, W. (2010). The Role of Functional Foods, Nutraceuticals and Food Supplements in Intestinal Healths, Nutriens, 2: 611-625.

Coşkun, F. (2014). Tarhananın Tarihi ve Türkiye'de Tarhana Çeşitleri, Gıda Teknolojileri Elektronik Dergisi, 9(3): 69-79.

Coşkun, F. (2017). A Traditional Turkish Fermented Non-Alcoholic Beverage, Shalgam, Beverages, 3(4).

Coşkun, T. (2005). Fonksiyonel Besinlerin Sağlığımız Üzerine Etkileri, Çocuk Sağhlğı ve Hastalıkları Dergisi, 48: 69-84.

Çakıroğlu, F. P. (2007). Geleneksel Tarhananın Modern Yolculuğu, ICANAS 38.Uluslararası Asya ve Kuzey Afrika Çalışmaları Kongresi, Atatürk Kültür, Dil ve Tarih Yüksek Kurumu 10-15 Eylül 2007. Ankara. ss: 339.

Çatır, O. ve Ay, E. (2018). Ulubey (Uşak) Yöresel Yemeklerinin Gastronomi Turizmi Açısından Değerlendirilmesi, Journal of Gastronomy Studies, 6(2): 3-19.

Daliri, E. B.M. and Lee, B.H. (2015). Perspektives on Functional Food and Nutraceuticals, (Editör) Liong, M.T.: Beneficial Micoorganisms in Food and Nutraceuticals 'Current Trends and Future içinde (ss. 221-240) Switzerland: Springer.

Demirgül, F. ve Sağdıç, O. (2018). Fermente Süt Ürünlerinin İnsan Sağlığına Etkisi, European Journal of Science and Technology, 13:45-53.

Dong, M., Yang, G., Liu, X., Lin, S., Sun, D. and Wang Y. (2014). Aged Black Garlic Extract İnhibits HT29 Colon Cancer Cell Growth via the PI3K/Akt Signaling Pathway, Biomedical Reports, 2(2): 250-254.

Durlu Özkaya, F. Özkaya, M. T., Tunalığlu, R., Bayar, R. ve Tunalığlu, E. (2018). Anadolu'da Zeytin ve Zeytinyağlı Yemekler Rotası, Journal of Tourism and Gastronomy Studies, 6(3): 263-274.

Ercan, A. (2015). Doğal Süper Gıdalar. (2.Basım), İstanbul: Hayy Kitap.

Erdoğan, Z. ve Oğuz, S. (2016). Kahve Tüketiminin Kalp Sağlığı Üzerine Etkisi, Journal of Cardiovascular Nursing, 7(14): 136-139.

Ertaş, Y. ve Akbulut, G. (2013). Kahve ve Diyabet, Türkiye Klinikleri, 8(2): 73-79.

Erten, H., Tangüler, H. and Canbaş, A. (2008). A Traditional Turkish Lactic Acid Fermented Beverage: Shalgam (Salgam), Food Reviews International, 24(3): 352-359. 
Fernandez, M. A. and Marette, A. (2017). Potential Health Benefits of Combining Yogurt and Fruits Based on Their Probiotic and Prebiotic Properties, Advances in Nutrition an International Review Journal, 8(1): 155-164.

Fisberg, M. and Machado, R. (2015). History of Yogurt and Current Patterns of Consumption, Nutition Reviews, 73(1): 4-7.

Göğüş, F., Ötles, S., Erdoğdu, F. and Özçelik, B. (2016). Functional and Nutritional Properties of Some Turkish Traditional Foods, (Editör) Kristbergsson, K. ve Ötles, S.: Functional Properties of Traditional Foods içinde (ss. 87-104) Switzerland: Springer.

Gülcü, M. (2012). Yemeklik Asma Yaprağ1 Üretimi. [Online] https://arastirma.tarimorman.gov.tr/bagcilik/Lists/KutuMenu/Attachments/3/ASMAYAPRAK.p df [Erişim Tarihi: 09.09.2019].

Güler, M.B. (1993). Çukurova Bölgesi Tarhanalarının Üretim Yöntemleri, Özellikleri ve Tarhana Üretiminde Soya Unundan Yararlanma Olanakları Üzerinde Bir Araştırma, Yayımlanmış Yüksek Lisans Tezi, Çukurova Üniversitesi, Adana.

Güzel-Seydim, Z. B., Kök-Taş, T., Greene, A. K. and Seydim, A. C. (2011). Review: Functional Properties of Kefir, Critical Reviews in Food Science and Nutrition, 51(3): 261-268.

Hasler, C. M. (2002). Functional Foods: Benefits, Concerns and Challenges-A Position Paper from the American Council on Science and Health, The Journal of Nutrition, 132(12): 3772-3781.

Hayta, M., Alpaslan, M. and Baysar, A. (2002). Effect of Drying Methods on Functional Properties of Tarhana: A Wheat Flour-Yogurt Mixture, Journal of Food Science, 67(2): 740-744.

http://apelasyon.com/Yazi/567-maviyemis-likapa-antioksidan-yildizi- [Erişim Tarihi: 10.09.2019] http://koculupeynircilik.com [Erişim Tarihi: 10.09.2019]

http://www.aydin24haber.com/her-derde-deva-siyah-sarimsak-181520h.htm [Erişim Tarihi: 10.09.2019]

http://www.gidagundemi.com/beslenme-ve-saglik/beslenme/turk-kahvesi-nasil-taze-kalirh14323.html [Erişim Tarihi: 10.09.2019]

http://www.hurriyet.com.tr/kelebek/saglik/kefir-neler-iyi-gelir-kefirin-faydalari-neler-40827271 [Erişim Tarihi: 10.09.2019]

http://www.hurriyet.com.tr/lezizz/zeytinyagli-enginar-tarifi-36802528 [Erişim Tarihi: 10.09.2019] http://www.siyezun.com/urunlerimiz.html [Erişim Tarihi: 10.09.2019]

http://www.yolculukterapisi.com/bogatepe/ [Erişim Tarihi: 08.09.2019].

https:/tr.pinterest.com/pin/520939881871778366/?lp=true [Erişim Tarihi: 10.09.2019]

https://van.ktb.gov.tr/TR-88271/otlu-peynir.html [Erişim Tarihi: 10.09.2019]

https://www.kisikates.com.tr/blog/tarhananin-tarihi-ve-yapilisi-168 [Erişim Tarihi: 10.09.2019]

https://www.kulturportali.gov.tr/arama/Geren+Kavurması [Erişim Tarihi: 10.09.2019]

https://www.ntv.com.tr/saglik/ev-yogurdu-hangi-hastaliklardan-

korur\%2ckIeYVq1BfEqge5ZAIG34NA [Erişim Tarihi: 10.09.2019]

https://www.sabah.com.tr/yemek-tarifleri/aperatifler/2016/02/10/mercimek-koftesi-nasil-yapilir [Erişim Tarihi: 10.09.2019]

https://www.saglampatent.com.tr/taskopru-sarimsagi-basari-hikayesi [Erişim Tarihi: 10.09.2019] 
https://www.sozcu.com.tr/2019/ekonomi/herkes-siyez-ekince-bugdaylar-tarlada-kaldi-5290432/ [Erişim Tarihi: 08.09.2019].

https://www.star.com.tr/saglik/gribin-en-etkili-ilaci-salgam-suyu-haber-1249662/ [Erişim Tarihi: 10.09.2019]

https://www.tokat.com/asma-yapraginin-faydalari-nelerdir-2-28869.html [Erişim Tarihi: 10.09.2019]

https://www.vakifzeytinleri.gov.tr/yemek-tarifleri/16/zeytinyagli-kabak-cicegi-dolmasi [Erişim Tarihi: 10.09.2019]

İşleroğlu, H., Yıldırım, Z. ve Yıldırım, M. (2005). Fonksiyonel Bir Gıda Olarak Keten Tohumu, GOÜ Ziraat Fakültesi Dergisi, 22(2): 23-30.

John, M. S. and Deeseenthum, S. (2015). Properties and Benefits of Kefir -A Review, Songklanakarin Journal of Science and Technology, 37(3): 275-282.

Kaplan, M. (2011). Bir Fincan Keyif: Kahvenin Öyküsü, Yurt ve Dünya Dergisi/The Journal of Homeland and The World, 2(2): 11-20.

Kara, Z. ve Akın, A. (2011). Müşküle Sofralık Üzüm Çeşidinde Gibberellik Asit (GA) Uygulamalarının Salamuralık Asma Yaprağı Üretimi ve Yaprakta Ham Sellüloz İçeriğine Etkileri, Selçuk Tarım ve Gıda Bilimleri Dergisi, 25(2): 42-45.

Karaçıl, M. Ş. ve Acar Tek, N. (2013). Dünyada Üretilen Fermente Ürünler: Tarihsel Süreç ve Sağlık ile İlişkileri, Uludă̆ Üniversitesi Ziraat Fakültesi Dergisi, 27(2): 163-173.

Kavas, G., Çelikel, N., Kınık, Ö. ve Gönç, S. (2006). Peynir, Peynir Suyunun Fosfor İçeriği ve İnsan Sağlığı Üzerindeki Etkileri, Türkiye 9. Gıda Kongresi, Bolu Abant İzzet Baysal Üniversitesi 01-04 Mayıs 2006. Bolu. ss: 197-200.

Kesenkaş, H., Gürsoy, O. and Özbaş H. (2017). Kefir (Editör) Frias, J., Martinez-Villaluenga, C. and Penas, E.: Fermented Foods in Health and Disease Prevention içinde (ss. 339-361) Boston: Academic Press.

Kim, D., Jung, S.J., Cheon, S.Y., Cho, Y.J., Tac, M.H., Kim, K.H. and Yook, H.S. (2013). Antioxidant Activity of Giant Black Garlic, Nutrition and Healthy Ageing, 72(OCE4): 305-764.

Köroğlu, Ö., Bakır, E., Uludağ, G., Köroğlu, S. ve Dayısoylu, K. S. (2015). Kefir ve Sağlık, KSÜ Doğa Bilimleri Dergisi, 18(1): 26-30.

Küçükkömürler, S. and Özgen, L. (2009). Coffee and Turkish Coffee Culture, Pakistan Journal of Nutrition, 8(10): 1693-1700.

Lourens- Hattingh, A. and Viljoen, B. C. (2001). Yogurt as Probiotic Carrier Food, International Dairy Journal, 11:1-17.

Orman Genel Müdürlüğü (2015). Maviyemiş-Likapa Eylem Planı 2015-2019. [Online] https://www.ogm.gov.tr/ekutuphane/Yayinlar/Maviyemis_Likapa_Eylem_Plani.pdf [Erişim Tarihi: 15.12.2018].

Özata, E. ve Cömert, M. (2016). Zeytinyağı ve Sağlıklı Yaşam, Zeytin Bilimi, 6(2): 105-110.

Özçelik, A. Ö. ve Özdoğan, Y. (2007). Tarhananın Türk Beslenme Kültüründeki Yeri ve Önemi. Uluslararası Asya ve Kuzey Afrika Çalışmaları Kongresi (ICANAS 38). 10-15 Eylül 2007. ss: 627-628.

Özçelik, M. M. (2015). Bitkisel Kaynaklı Bazı Fonksiyonel Gıdalar, Biyoloji Bilimleri Araştırma Dergisi, 9(1): 57-68. 
Patel, S. (2014). Bluebeery as Functional Food and Dietary Supplement: The Natural Way to Ensure Holistic Health, Mediterranean Journal of Nutrition of Metabolism, 7: 33-143.

Rafter, J. J. (2002). Scientific Basis of Biomarkers and Benefits of Functional Foods for Reduction of Disease Risk: Cancer, British Journal of Nutrition, 88(2): 219-224.

Resmi Gazete (2009). Fermente Süt Ürünleri Tebliği [Online] http://www.resmigazete.gov.tr/eskiler/2009/02/20090216-8.htm [Erişim Tarihi: 20.12.2018].

Riezzo, G., Chiloiro, M. and Russo, F. (2005). Functional Foods: Salient Features and Clinical Applications, Current Drug Targets Immune Endocrine and Metabolic Disorders, 5(3): 331-337.

Roberfroid, M. B. (2002). Global View on Functional Foods: European Perspectives, British Journal of Nutrition, 88(2): 133-138.

Sayın, I. (2010). Asma Yaprağı ve Beslenme: Bilinmeyen Cevher Asma Yaprağı. [Online] https://www.tavsiyeediyorum.com/makale_5603.htm [Erişim Tarihi: 09.09.2019].

Sengun, İ. Y., Dennis, S. N., Karapınar, M. and Jakopsen, M. (2009). Identification of Lactic Acid Bacteria Isolated from Tarhana, A Traditional Turkish Fermented Food, International Journal of Food Microbiology, 135(2): 105-111.

Sevilmiş, G. (2008). Bazı Fonksiyonel Gıdalarda Tüketici Kararları ve Bunları Etkileyen Faktörlerin Belirlenmesi Üzerine Bir Araştırma, Yayımlanmış Yüksek Lisans Tezi, Ege Üniversitesi, İzmir.

Singh, R. B., Tomar, R.S., Chauhan, A. K., Yadav, P. and Khan, S. (2019). Estimates of Functional Foods Availability in the 10 Most Highly Populous Countries, (Editör) Singh, R.B., Watson, R.R. and Takahashi, T.: The Role of Functional Food Security in Global Health içinde (ss. 25-42) Academic Press.

Slow Food Foundation (2015). Boğatepe Gravyer. [Online] https://www.fondazioneslowfood.com/en/slow-food presidia/bog\%CC\%86atepe-gravyer/ [Erişim Tarihi: 09.12. 2018].

Slow Food Foundation (2018). Siyez Wheat Bulgur. [Online] https://www.fondazioneslowfood.com/en/slow-food-presidia/siyez-wheat-bulgur/ [Erişim Tarihi: 09.12.2018].

Sormaz, Ü., Onur, N., Güneş, E. ve Nizamoğlu, H.F. (2019). Türk Mutfağı Geleneksel Ürünlerinde Yöresel Farklılıklar: Tarhana Örneği, Aydın Gastronomy, 3(1): 1-9.

Şireli, U. ve Onaran, B. (2016). Yoğurt ve Yoğurdun İnsan Sağğı̆̆ Açısından Yararları. [Online] http://www.asuder.org.tr/wp-content/uploads/2016/03/yogurt.pdf [Erişim Tarihi: 25.06.2019].

T.C Tarım ve Orman Bakanlığı (2018). Otlu Peynir. [Online] https://van.tarimorman.gov.tr/Sayfalar/Detay.aspx?SayfaId=20 [Erişim Tarihi: 29.12.2018].

T.C. Başbakanlık Devlet Planlama Teşkilatı Müsteşarlığı ve Japonya Uluslararası İş Birliği Ajansı (2004). Doğu Karadeniz Bölgesinde Turizmin Geliştirilmesine Yönelik Kalkınma Çalışması. [Online] http://open_jicareport.jica.go.jp/pdf/11755113.pdf_[Erişim Tarihi: 29.12.2018].

T.C. Kastamonu Valiliği (2016). Siyez Bulguru. [Online] https://kastamonu.tarimorman.gov.tr/Belgeler/Kutu\%20Men\%C3\%BC/Siyez $\% 20 \mathrm{Bu} \% \mathrm{C} 4 \% 9 \mathrm{Fday}$ \%C4\%B1\%20ve\%20Bulguru.pdf [Erişim Tarihi: 06.12.2018].

T.C. Kültür ve Turizm Bakanlı̆̆1 (2013). Türk Kahvesi Kültürü ve Geleneği. [Online] http://aregem.kulturturizm.gov.tr/TR-202374/turk-kahvesi-kulturu-ve-gelenegi.html [Erişim Tarihi: 01.01.2019]. 
T.C. Kültür ve Turizm Bakanlığı (2019). Tokat Mutfağı. [Online] http://www.tokatkulturturizm.gov.tr/TR-143211/tokat-mutfagi.html [Erişim Tarihi: 01.01.2019].

Takahashi, T., Singh, R.B., Chibisov, S., Tomar, R.S., Charkrabarti, T., Chauhan, A.K., Onsaard, T., Phomkong, W., Chaves, H., Singh, M., Srivastav, R., Srivastav, M., Singh, R.G. and Jaglan, P. (2019). The Singh's Concept of Functional Foods and Functional Farming (4 F) for World Health, (Editör) Singh, R.B., Watson, R.R. ve Takahashi, T.: The Role of Functional Food Security in Global Health içinde (ss. 43-56) Academic Press.

Tez, Z. (2018). Lezzetin Tarihi. (4. Basım), İstanbul: Hayy Kitap.

Tomar, O., Çağlar, A. ve Akarca, G. (2017). Kefir ve Sağlık Açısından Önemi, Afyon Kocatepe Üniversitesi Fen Bilimleri ve Mühendislik Dergisi, 17: 834-853.

Topuk, Ş. (2014). Kars Gravyer Peynirlerinin Kalitelerinin Araştırılması, Yayımlanmış Yüksek Lisans Tezi, Kafkas Üniversitesi, Kars.

Tunçtürk, Y., Ocak, E. ve Köse, Ş. (2014). Farklı Süt Türlerinden Üretilen Van Otlu Peynirlerinin Fiziksel ve Kimyasal Özellikleri ile Proteoliz Profillerinde Olgunlaşma Sürecinde Meydana Gelen Değişimler, Gıda, 39(3): 163-170.

Turker, N., Aksay, S., and Ekiz, H.I. (2004). Effects of Storage Temperature on the Stability of Anthocyanins of a Fermented Black Carrot (Daucus carota var. L.) Beverage: Shalgam. Journal of Agricultural and Food Chemistry, 52(12): 3807-3813.

Türk Patent Enstitüsü (2009). Coğrafi Işaret Tescil Belgesi, [Online] http://www.turkpatent.gov.tr/ [Erişim Tarihi: 18.12.2018].

Türk Patent Enstitüsü (2009). Coğrafi İşaret Tescil Belgesi. [Online] https://www.turkpatent.gov.tr/TURKPATENT/resources/temp/F2265BC1-21A0-454F-A962-

15EAECDF9158.pdf;jsessionid=E463ED3DBE14DF829C587747424BBF62 [Erişim Tarihi: 08.08.2019].

Türk Patent Enstitüsü (2019). Coğrafi İşaret Tescil Belgesi. [Online] https://www.turkpatent.gov.tr/TURKPATENT/resources/temp/C9D0546E-A56C-4C56-A54F671C5DF54990.pdf [Erişim Tarihi: 08.09.2019].

Türkmen, N. (2017). Kefir as a Functional Dairy Product, (Editör) Watson, R. R., Collier, R. J. ve Preedy, V. R.: Dairy in Human Health and Disease Across the Lifespan içinde (ss. 373-383) Academic Press.

Üçok, E. F. ve Tosun, H. (2012). Şalgam Suyu Üretimi ve Fonksiyonel Özellikleri, C.B.Ü. Fen Bilimleri Dergisi, 8(1): 17-26.

Visioli, F., Franco, M., Toledo, E., Luchsinger, J., Willett, W.C., Hu, F.B. and Martinez-Gonzalez, M.A. (2018). Olive Oil and Prevention of Chronic Diseases: Summary of International Conference, Nutrition, Metabolism and Cardiovascular Diseases, 28(7): 649-656.

Vural, A. (2004). Fonksiyonel Gıdalar ve Sağlık Üzerine Etkileri, Gıda ve Yem Bilimi Teknolojisi, 6: 51-58.

Wang, J., Chen, M., Sun, L. and Yuan, H. (2016). The Comparison of the Contents of Sugar, Amadori and Heyns Compounds in Fresh and Black Garlic, Journal of Food Science, 81(7): 16621668.

Wu, J., Ho, S.C., Zhou, C., Ling, W., Chen, W., Wang, C. and Chen, Y. (2009). Coffee Consumption of Risk of Coronary Heart Diseases: A Meta-analysis of 21 Prospective Cohort Studies, International Journal of Cardiology, 137: 216-225. 
Yavuz, C. (2005). Doğu Karadeniz Bölgesi'nin Alternatif Turizm Olanakları: Eko Turizm ve Pazarlanabilirliği, Doğu Karadeniz Bölgesi Kalkınma Sempozyumu, Karadeniz Teknik Üniversitesi 13-14 Ekim 2005. Trabzon. ss: 57-66.

Yoo, J.M., Sok, D.E. and Kim, M.R. (2014). Anti-Allergic Action of Aged Black Garlic Extract in RBL-2H3 Cells and Passive Cutaneous Anaphylaxis Reaction in Mice, Journal of Medicinal Food, 17(1): 92-102.

Yorulmaz, A. ve Tekin, A. (2008). Zeytin ve Zeytinyağı Fenolikleri, I. Ulusal Zeytin Öğrenci Kongresi, Balıkesir Üniversitesi 17-18 Mayıs 2008. Balıkesir. ss: 24-31.

Zağralı, E. ve Akbaba, A. (2015). Turistlerin Destinasyon Seçiminde Yöresel Yemeklerin Rolü: İzmir Yarımadasını Ziyaret Eden Turistlerin Üzerine Bir Araştırma, Journal of Yasar University, 10(40): 6633-6644.

Zaharieva, M. and Monnoveux, P. (2014). Cultivated Einkorn Wheat (Triticum monococcum L. subsp. monococcum): The Long Life of a Founder Crop of Agriculture, Genetic Resources and Crop Evolution, 61(3): 671-776. 